\title{
The sensitivity of two Monoraphidium species to zinc: their possible future role in bioremediation
}

\author{
I. Bácsi $\cdot$ Z. Novák $\cdot$ M. Jánószky • V. B-Béres • \\ I. Grigorszky $\cdot$ S. A. Nagy
}

Received: 10 January 2014/Revised: 8 April 2014/ Accepted: 8 July 2014/Published online: 23 July 2014

(C) Islamic Azad University (IAU) 2014

\begin{abstract}
Effects of zinc on growth, cell morphology, oxidative stress responses and zinc removal activity of two common phytoplankton species, Monoraphidium pusillum (Printz) Komárková-Legnerová and Monoraphidium griffithii (Berkeley) Komárková-Legnerová were investigated at a concentration range of $0.2-160 \mathrm{mg} \mathrm{l}^{-1}$ zinc. Cell densities and chlorophyll content decreased compared with controls in cultures of both species, effective concentrations causing $50 \%$ growth inhibition within $72 \mathrm{~h}$ on the basis of cell numbers were 33.69 and $25.63 \mathrm{mg} \mathrm{l}^{-1}$ zinc for M. pusillum and M. griffithii, respectively. Changes in cell morphology and elevated lipid peroxidation levels appeared in zinc-treated cultures of both species, but only at higher $\left(>10 \mathrm{mg} \mathrm{l}^{-1}\right)$ zinc concentrations. The most effective zinc removal appeared at 20 and $10 \mathrm{mg}^{-1}$ zinc concentration for $M$. pusillum and M. griffithii, respectively. Removed zinc is mainly bound on the cell surface in the case of both species. This study provides new data for the zinc tolerance and zinc removal ability of the green algae $M$. pusillum and $M$. griffithii and shows that green algal species common in surface waters could have zinc tolerance and zinc-binding abilities, which makes them feasible in treatment of waters contaminated with 10-20 $\mathrm{mg}^{-1}$ zinc.
\end{abstract}

I. Bácsi $(\bowtie)$ · Z. Novák · I. Grigorszky · S. A. Nagy Department of Hydrobiology, University of Debrecen, Egyetem tér 1, 4032 Debrecen, Hungary

e-mail: istvan.bacsi@gmail.com

M. Jánószky · V. B-Béres

Environmental Protection and Nature Conservation Authority, Trans-Tiszanian Region, Hatvan u. 16, 4025 Debrecen, Hungary
Keywords Common green algal species $\cdot$ Zinc $\cdot$ Growth inhibitions · Morphological changes $\cdot$ Lipid peroxidation · Removal

\section{Introduction}

It is well known that the presence of heavy metals in aquatic environments causes serious damage to aquatic life. These metals can reduce the effectiveness of purification processes during biological treatment of wastewater by damaging microorganisms (e.g., bacteria, protozoa). Lots of metal salts are soluble in water and consequently cannot be separated by physical separation (Hussein et al. 2004). Physico-chemical methods, such as evaporative recovery, chemical oxidation or reduction, chemical precipitation and filtration, electrochemical treatment, ion exchange, or membrane technologies have been widely used to remove heavy metal ions from wastewater. The main problem of these processes is that they may be ineffective and/or rather expensive, when the concentration of dissolved metal ions is lower than $100 \mathrm{mg} \mathrm{l}^{-1}$ (Volesky 1990a, b). Biological methods for the removal of metal ions may provide an attractive and cost-effective alternative to physico-chemical methods (Kapoor and Viraraghavan 1995), since many microorganisms are able to remove metal ions from aquatic solutions by metabolically active (bioaccumulation) and/or passive (biosorption) processes (Chojnacka 2010).

Algae are in the focus of scientific interest because of their mass productions (blooms) and possible toxic properties (Perovic et al. 2000; Vasas et al. 2012; Zhang et al. 2012). Algae play more and more important roles in a wide range of economical and environmental issues in the last few years, obviously they are also involved in wastewater treatment and sequestering of toxic, essential or precious 
metals (Munoz and Guieysse 2006; de Bashan and Bashan 2010; Das 2010). Algal cell wall has a key role in metal removal, especially in biosorption processes, which are also important in metal binding of living biomass. Cell wall of green algae (Chlorophyta) is composed mainly from cellulose, and a high percentage of the cell wall is structured from glycoproteins, proteins bound to polysaccharides (Romera et al. 2006). Over the metal-binding capability of cell wall, microalgae and some fungi are able to produce peptides capable to bind heavy metals. These molecules, as organometallic complexes, are further partitioned inside vacuoles. They facilitate the control of the cytoplasmic concentration of heavy metal ions, thus preventing or neutralizing the potential toxic effects (Cobbett and Goldsbrough 2002). It is difficult to decide whether algal biomass is better or not than others (bacterial or fungal). The results of various studies are not easy to compare directly due to the different data presentation of various authors' (Wang and Chen 2009). Nevertheless, study of photosynthetic organisms is justifiable, because there are generally accepted procedures in wastewater treatment technology, in which the presence of these organisms can be considered, or easy to implement (Perales-Vela et al. 2006).

Over the well-studied aspects of toxic heavy metals $(\mathrm{Cr} ; \mathrm{Cd} ; \mathrm{Pb})$, effects of trace elements $(\mathrm{Fe} ; \mathrm{Cu} ; \mathrm{Zn})$ on the growth of phytoplankton species still have been in the focus of interest for a long time. Zinc is an essential trace element, necessary for living organisms (Sugarman 1983; Broadley et al. 2007; Prasad 2008). Zinc is found in a great number of specific enzymes (US NRC 2000), serves as structural ion in transcription factors and is stored and transferred in metallothioneins (Cotton et al. 1999). Zinc is known as the second most abundant transition metal after iron in organisms, and it is the only metal that appears in all enzyme classes (Broadley et al. 2007). Although zinc is essential, excess of this element can be toxic. Excessive absorption of zinc suppresses copper and iron absorption (Fosmire 1990). Free zinc ion in solution can be highly toxic (Eisler 1993), and many data in the literature show that just micromolar amounts of the free ion cause the death of some organisms (Muyssen et al. 2006). Zinc resistance of microalgae varies within a very wide range (from several $\mathrm{mg} \mathrm{l}^{-1}$ to several hundreds of $\mathrm{mg} \mathrm{l}^{-1}$ (Travieso et al. 1999; Nishikawa and Tominaga 2001; Li et al. 2006; Monteiro et al. 2009, 2011a, b). In general, it can be said that many microalgae can bind significant amounts of zinc (Brinza et al. 2007). The above-mentioned cell wall properties and phytochelatin production abilities are behind this phenomenon. Similarly to other metals, elevated zinc levels may cause morphological changes or oxidative stress in microorganisms, including algae (Gold et al. 2003; Morin and
Coste 2006; Tripathi and Gaur 2006; Li et al. 2006). Effective concentrations depend on the tolerance/sensitivity of algal species. Laboratory studies showed that zinc pretreatment could enhance the tolerance of algae toward toxic metals others than zinc (e.g. $\mathrm{Cd}, \mathrm{Hg}, \mathrm{Cu}, \mathrm{Pb}$; Lehmann et al. 1998; Tsuji et al. 2002), so zinc-tolerant species could be good subjects of biosorbent, metallothionein or phytochelatin research (Andrade et al. 2004; Perales-Vela et al. 2006). To take these facts into consideration, it is reasonable to study the metal tolerance and removal ability of inland algal species, which could have relevant potential in water treatment.

Monoraphidium species are applied for several biotechnological events (Fujii et al. 2009; Gattullo et al. 2012; Yang et al. 2012; Yu et al. 2012). There are a few data about metal tolerance and metal removal ability of Monoraphidium species (Hornstrom et al. 1995; Palmieria et al. 2000; Takami et al. 2012; de Queiroz et al. 2012), but according to our knowledge, there are no data about their zinc tolerance.

Although the average zinc concentration ranges from 5 to $100 \mu \mathrm{g} \mathrm{l}^{-1}$ in Hungarian surface waters, zinc is one of the most abundant metal contaminant in wastewaters in Hungary. Zinc concentration can be increased in consequence of mining or industry (electroplating plants, pharmaceutical companies, paint factories), moreover household and traffic activities (Horváth and Gruiz 1996; Ódor et al. 1998; Bird et al. 2003). The aim of this study was to investigate the effects of zinc on growth, cell morphology, oxidative stress responses, and zinc removal activity of phytoplankton species, which are common in Hungarian surface waters. Green algae Monoraphidium pusillum and Monoraphidium griffithii were treated with zinc in a wide concentration range $\left(0.2-160 \mathrm{mg} \mathrm{l}^{-1}\right)$ to get detailed data of the sensitivity and zinc removal ability, hereby the possible future role of these widespread algae of surface waters in bioremediation. Experiments were carried out in 2012-2013, on the Department of Hydrobiology, University of Debrecen, Debrecen, Hungary.

\section{Materials and methods}

Strains, culturing conditions, and experimental design

Monoraphidium pusillum (Printz) Komárková-Legnerová (ACCDH-UD0911) and M. griffithii (Berkeley) Komárková-Legnerová (ACCDH-UD1008) are cultured in the Algal Culture Collection of Department of Hydrobiology, University of Debrecen (ACCDH-UD). Cultures are maintained in Jaworski's medium (pH: 7-7.5), in 250-ml Erlenmeyer flasks (200 ml culture per flask), bubbled with 
sterile air, at $24{ }^{\circ} \mathrm{C}$, under continuous irradiation. Treatments were achieved within the same conditions, in 500-ml Erlenmeyer flasks (400 ml culture per flask). Control cultures contained no added zinc, and $\mathrm{ZnSO}_{4}$ (Reanal, Hungary) was added to the treated cultures to reach $0.25,0.5,1.0,1.5,2.0,2.5,5.0,10,20,40,80,120$ and $160 \mathrm{mg} \mathrm{l}^{-1}$ zinc concentrations. Negative controls (medium + zinc, without algae) were applied for all zinc concentrations to check the maintenance of the metal concentration added to the culture medium during the timeframe of the experiments (7 days). All experiments were done in triplicates.

Growth of the control and treated cultures was followed by counting the cell number and measuring the chlorophyll $a$ content and dry mass of the cells. Cell numbers were counted according to the European Standard EN 15204 (2006) using an Olympus BX50 fluorescent microscope at $400 \times$ magnification. Changes in cell morphology were followed by the same microscope at $1,000 \times$ magnification, on days 0,3 and 7 of the experiments.

For chlorophyll content and dry mass measurements, $6 \mathrm{ml}$ samples were collected daily, centrifuged $(5 \mathrm{~min}$, 10,000 rpm, Micro-centrifuge Type-320a), and after removal of supernatants, pellets were lyophilized (Christ Alpha 1-2 LD plus) and weighed (Ohaus Adventurer ${ }^{\mathrm{TM}}$ Pro). Chlorophyll $a$ contents were measured from the weighed samples applying the methanolic extraction method of Felföldy (1987). Spectroquant Pharo 300 spectrophotometer was used for the spectrophotometric measurements.

\section{Measurement of changes in lipid peroxidation}

Lipid peroxidation levels were measured in significantly affected, but still considered as living cultures and were expressed as the amount of thiobarbituric acid reactive substances (TBARS), following the method of Verma and Dubey (2003). Samples of $6 \mathrm{ml}$ were collected at days 0 and after $72 \mathrm{~h}$, samples were centrifuged $(5 \mathrm{~min}$, 10,000 rpm, Micro-centrifuge Type-320a) and after removal of supernatants, pellets were used for the reactions. Briefly: pellets were resuspended in $1 \mathrm{ml}$ of $0.25 \%$ (w/v) 2-thiobarbituric acid (TBA) in $10 \%(\mathrm{w} / \mathrm{v})$ trichloroacetic acid (TCA). Mixtures were incubated at $95{ }^{\circ} \mathrm{C}$ for $30 \mathrm{~min}$, and then, they were quickly cooled in ice bath and centrifuged ( $5 \mathrm{~min}, 10,000 \mathrm{rpm}$, Micro-centrifuge Type320a). The absorbance of supernatants was measured at 532 and $600 \mathrm{~nm}$ (for correction of unspecific turbidity). TBA solution in TCA served as blank. Amounts of TBARS were calculated to unit of cell number using the extinction coefficient of $1.56 \times 10^{5} \mathrm{M}^{-1} \mathrm{~cm}^{-1}$. Results are given in percentage, and $100 \%$ is the value that was measured in control culture at the beginning of the treatments.
Measurement of the total amount of removed zinc

Zinc contents of the cell-free supernatants were measured according to the Hungarian Standard MSZ 1484-3:2006 5. by Atom Absorption Spectrometry (AAS, UNICAM 969 with GF90 plus oven transformer and FS90 plus oven sample tray unit), in the laboratory of Environmental Protection, Nature Conservation and Water Authority, Trans-Tiszanian Region. Samples of $6 \mathrm{ml}$ from significantly affected, but still considered as living cultures, were collected at days 0,3 , and 7 of the experiments and centrifuged (5 min, 10,000 rpm, Micro-centrifuge Type-320a) and zinc contents of supernatants were measured. Ten-fold diluted samples of $20 \mu \mathrm{l}$ were measured, and all measurements were done in triplicate. For calibration, MERCK ICP IV multielement standard was used. Zinc precipitation in negative controls (medium + zinc, without algae) were measured and calculated by the same way. Amounts of zinc removed by the cells were calculated based on decreasing zinc contents of the supernatants, corrected with the amount of precipitated zinc. Results were given to unit of dry mass.

Measurement of intracellular level of zinc

Intracellular zinc content was measured according to the method described by Tripathi and Gaur (2006). To define intracellular zinc content, $6 \mathrm{ml}$ samples from significantly affected, but still considered as living cultures, were collected at days 0,3 , and 7 of the experiments. The algal suspensions were centrifuged ( $5 \mathrm{~min}, 10000 \mathrm{rpm}$, Microcentrifuge Type-320a), and after removal of supernatants, pellets were washed in $5 \mathrm{ml}$ of $2 \mathrm{mM}$ EDTA for $10 \mathrm{~min}$ to remove all of the surface-bound zinc without any effect on the internal zinc content. After centrifugation, pellets were transferred to $5 \mathrm{ml}$ of digestion mixture containing $\mathrm{HNO}_{3}$ $(70 \%), \mathrm{H}_{2} \mathrm{O}_{2}(30 \%)$, and deionised water at a 1:1:3 ratio (Bates et al. 1982). Digestion was performed on a hot plate at $80{ }^{\circ} \mathrm{C}$ until the solutions became colorless. The residues were dissolved in $2 \%(\mathrm{v} / \mathrm{v})$ nitric acid and were adjusted to a final volume of $5 \mathrm{ml}$. The samples were analyzed for zinc content by AAS.

Statistical analyses

One-way ANCOVA was used to determine the significances among the tendency differences of growth curves of control and treated cultures (Zar 1996; Hammer et al. 2001). For statistics of morphology changes, oxidative stress and zinc removal data were subjected to analysis of variance (two-way ANOVA). Tukey's test as multiple comparison procedure was used to show the significant differences between means at the $5 \%$ level. 

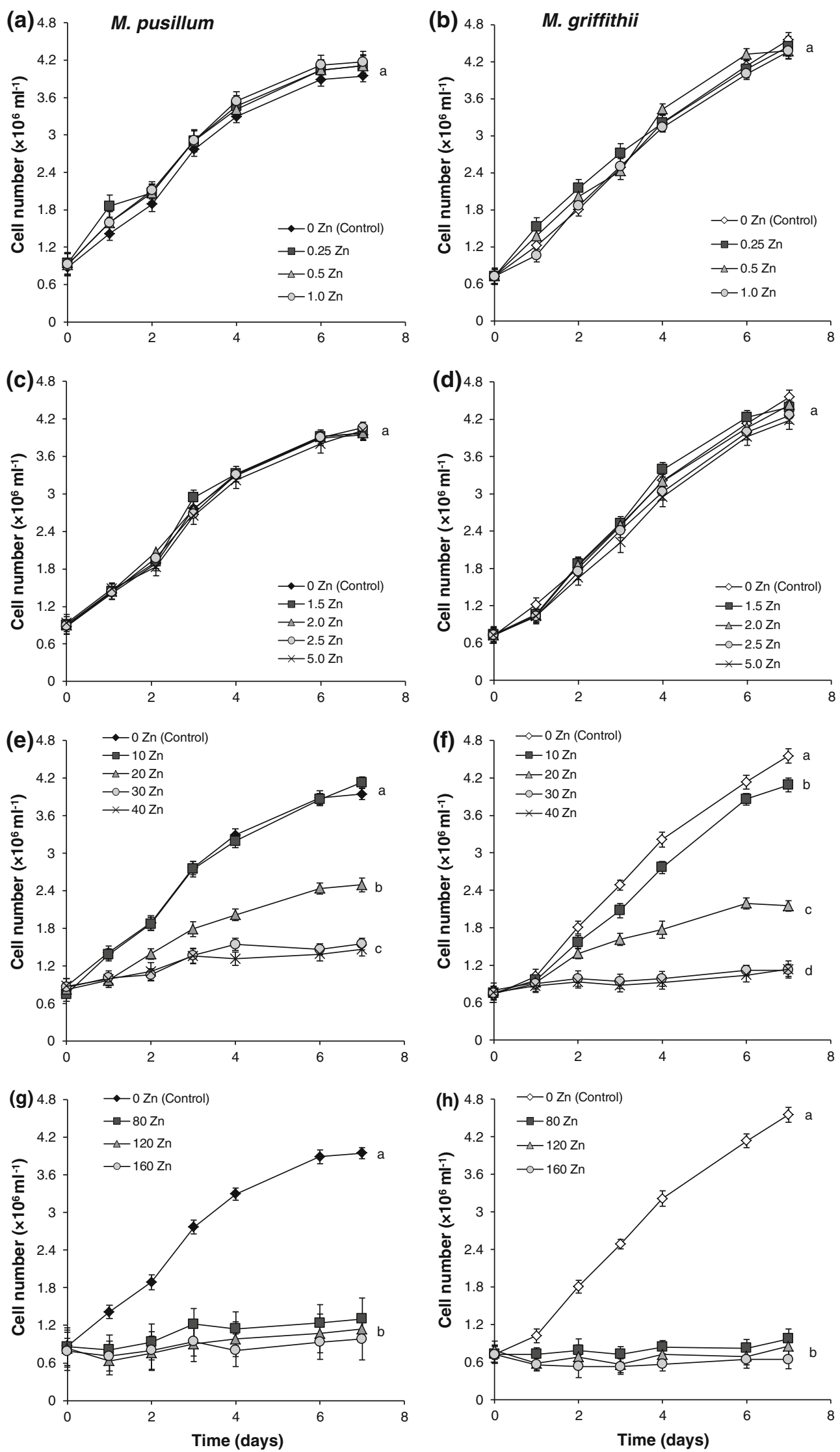
4Fig. 1 Changes of cell numbers in control cultures and in cultures with different initial zinc concentrations of $M$. pusillum and $M$. griffithii green algae. Mean values $(n=3)$ and standard deviations are plotted, and different lowercase letters indicate significant differences $(P<0.05)$

\section{Results and discussion}

Growth of the cultures

Both in M. pusillum and M. griffithii cultures, 0.25, 0.5, and $1.0 \mathrm{mg} \mathrm{l}^{-1}$ zinc caused slight, but not significant increase in cell number compared with control cultures (Fig. 1a, b). Zinc concentrations from 1.5 to $10 \mathrm{mg} \mathrm{l}^{-1}$ did not cause significant alterations in cell numbers (Fig. 1c, d). Treated cultures differed significantly from control cultures only from 20 and $10 \mathrm{mg} \mathrm{l}^{-1}$ zinc in the case of M. pusillum and $M$. griffithii, respectively $(P<0.001$; Fig. $1 \mathrm{e}, \mathrm{f})$, so the sensitivity of the two species was different on the basis of cell number. There were no significant differences among the effects of zinc in concentrations higher than $40 \mathrm{mg} \mathrm{l}^{-1}$ (80, 120 and $160 \mathrm{mg} \mathrm{l}^{-1}$, Fig. $\left.1 \mathrm{~g}, \mathrm{~h}\right)$. Growth of the cultures was strongly inhibited, but it has to be noted that $M$. pusillum showed a slight increase in cell numbers even at the presence of $160 \mathrm{mg}^{-1}$ zinc.

As it was observed in the case of cell number changes, M. pusillum was less sensitive to zinc than M. griffithii also on the basis of chlorophyll $a$ content. Lower zinc concentrations $\left(0.25-5 \mathrm{mg} \mathrm{l}^{-1}\right)$ did not cause significant alterations in chlorophyll $a$ content of $M$. pusillum cultures, but significantly lower chlorophyll $a$ level was measured in M. griffithii cultures treated with $1.0 \mathrm{mg}^{-1}$ and higher zinc concentrations (Fig. 2a-d). While there was detectable increases in cell numbers at high zinc concentrations, chlorophyll content remained at low level or decreased at higher zinc concentrations (from 20 and $10 \mathrm{mg} \mathrm{l}^{-1}$ in the case of M. pusillum and M. griffithii, respectively, Fig. 2eh). Table 1 summarizes the actual zinc concentrations and the calculated amount of precipitated zinc in negative controls (medium + zinc, without algae) for significantly affected, but still considered as living cultures. Growth curves and $\mathrm{EC}_{50}$ values showed that inhibition of chlorophyll synthesis occurred at lower zinc concentration than the inhibition of cell division (Figs. 1, 2; Table 2).

As far as we know, these are the first data about zinc tolerance of these Monoraphidium species, which can be characterized as zinc-tolerant ones. Comparison of literary data with each other and with our results may not be entirely accurate because of different measured growth parameters and exposition times, yet it seems that the zinc tolerance of the studied Monoraphidium species is in the "medium range" in comparison with the zinc tolerance of some other green algae. Growth rates of extremely zinc-tolerant species, such as a Chlorella vulgaris and a Scenedesmus acutus strain, did not differ from controls in the presence of $100-300$ and $125 \mathrm{mg} \mathrm{l}^{-1}$ zinc, respectively (Travieso et al. 1999). $\mathrm{EC}_{50}$ was $300 \mathrm{mg} \mathrm{l}^{-1}$ zinc in the case of a Chlamydomonas acidophila strain (Nishikawa and Tominaga 2001). On the other hand, there are species much more sensitive to zinc than the ones in our study. Tripathi and Gaur (2006) observed that $1.64 \mathrm{mg} \mathrm{l}^{-1}$ zinc inhibited the growth of a Scenedesmus strain within $48 \mathrm{~h}$. Zinc concentration of $6.5 \mathrm{mg} \mathrm{l}^{-1}$ caused growth inhibition and oxidative stress in a Pavlova viridis strain ( $\mathrm{Li}$ et al. 2006).

\section{Changes in cell morphology}

Morphological changes were followed in significantly affected, but considered as living cultures (from 10 to $40 \mathrm{mg} \mathrm{l}^{-1}$ treatments). Zinc treatments caused changes in cell morphology of both studied species, but the changes were different. The chloroplasts and later the whole cells of M. pusillum became fragmented, and the cells precipitated and sunk to the bottom of the flasks. Linear correlation was observed between these phenomena and the increasing concentration of zinc. In the case of $M$. pusillum, the number of deformed cells in control and in treated cultures differed significantly from each other in every case $(P<0.001$, Fig. 3a). Cell morphology changes of $M$. griffithii were barely detectable: $M$. griffithii cells became slightly more swollen than in control cultures, flocculation also occurred. Significant differences $(P<0.001)$ were among numbers of deformed cells in control and treated cultures of $M$. griffithii, but numbers of deformed cells did not differed significantly from each other, only in 30 and $40 \mathrm{mg}^{-1}$ treatments (Fig. 3b).

Morphology changes of algal taxa as a response to zinc contamination strongly depend on ecotype of the taxa (Pawlik-Skowronska 2003), on the concentration of zinc and on the time of exposure (Gold et al. 2003; Morin and Coste 2006). In sensitive species (e.g., filamentous green algae as Stigeoclonium tenue or certain diatoms), these morphological changes appear at low zinc concentrations (Pawlik-Skowronska 2003; Gold et al. 2003; Morin and Coste 2006). It is known that metals able to inhibit normal cell division due to binding to sulfhydryl groups, which are important in regulating cell division (Visviki and Rachlin 1991). In the case of the studied Monoraphidium species, cell morphology changes appeared only from relatively high zinc concentration $\left(10 \mathrm{mg} \mathrm{l}^{-1}\right)$. There was detectable increase in cell number in M. pusillum cultures treated with $40 \mathrm{mg} \mathrm{l}^{-1}$ zinc, this could be the reason of highest abundance of abnormal cells. Increasing mitotic abnormalities caused by zinc could be one of the reasons of this phenomenon. Morphological changes seemed not to be highly 

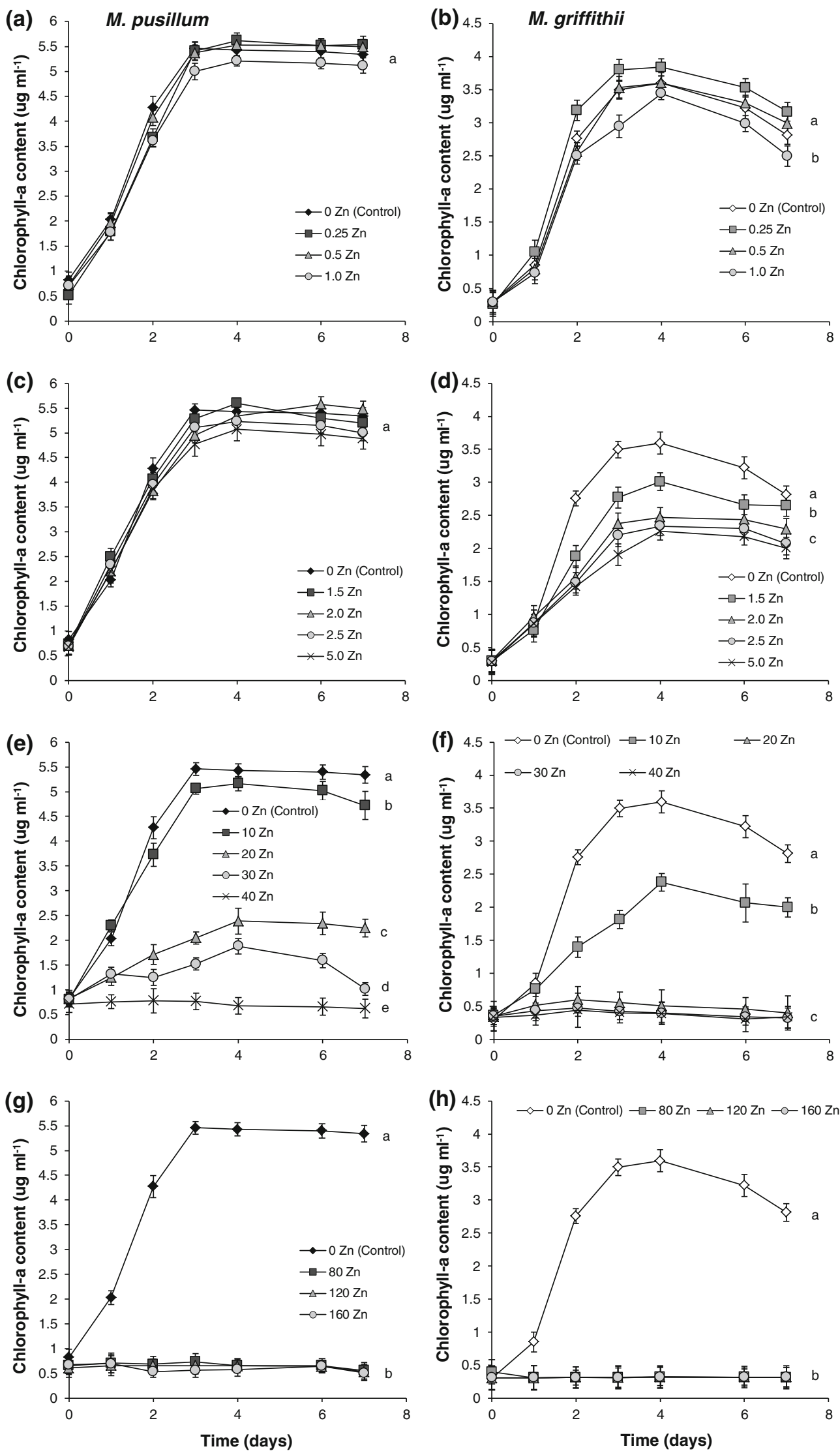
4Fig. 2 Changes of chlorophyll $a$ contents in control cultures and in cultures with different initial zinc concentrations of $M$. pusillum and M. griffithii green algae. Mean values $(n=3)$ and standard deviations are plotted, and different lowercase letters indicate significant differences $(P<0.05)$

specific or characteristic to zinc treatment in the studied green algae, contaminants affecting cell division other than zinc, may cause similar morphological changes.

\section{Changes of lipid peroxidation levels}

Oxidative stress responses were followed in significantly affected, but considered as living cultures (from 10 to $40 \mathrm{mg}^{-1}$ treatments). The amount of TBARS increased in proportion to the increasing zinc concentration in M. pusillum cultures. There were no significant differences between control and $10 \mathrm{mg} \mathrm{l}^{-1}$ treatment. The other treatments differed significantly from control, but not from each other (Fig. 4a). TBARS levels did not differed significantly in control and in $10 \mathrm{mg} \mathrm{l}^{-1}$ zinc-treated $M$. griffithii cultures, but significant differences were observed between control and among the other treatments $(P<0.001)$. The highest TBARS concentration was measured at $30 \mathrm{mg}^{-1}$ zinc treatment (Fig. 4b). 30 and $40 \mathrm{mg} \mathrm{l}^{-1}$ initially added zinc caused significantly higher increase in TBARS levels in $M$. griffithii cultures than in M. pusillum cultures $(P<0.001)$. M. griffithii seemed to be more sensitive from enzymological point of view: $30-40 \mathrm{mg} \mathrm{l}^{-1}$ initially added zinc caused $200 \%$ increase in the amount of TBARS within $72 \mathrm{~h}$ comparing to control. This value is 1.2-1.5-fold higher than that of M. pusillum.

Algae show great diversity in oxidative stress responses to zinc, as it is indicated by our results and literary data. There were detectable increasing amount of TBARS in a Scenedesmus sp. already from $5 \mu \mathrm{M}$ zinc $\left(\sim 0.3 \mathrm{mg} \mathrm{l}^{-1}\right.$, Tripathi and Gaur 2004). Zinc was observed to cause an increase in glutathione pools, in particular of glutathione disulfide (GSSG), causing a decrease of its redox ratio, i.e., to cause oxidative stress in Enteromorpha species already from 0.1 to $0.2 \mathrm{mg} \mathrm{l}^{-1}$ (Malea et al. 2006). On the other hand, lipid peroxidation levels in Chlorella pyreonidosa increased only from $30 \mu \mathrm{M}$ zinc $\left(\sim 2 \mathrm{mg}^{-1}\right.$; Vavilin et al. 1998), or from $6.5 \mathrm{mg} \mathrm{l}^{-1}$ in P. viridis ( $\mathrm{Li}$ et al. 2006).
Table $2 \mathrm{EC}_{50}$ values calculated to cell number and to chlorophyll $a$ content after 3 and 7 days of exposition

\begin{tabular}{|c|c|c|c|c|}
\hline $\begin{array}{l}\mathrm{EC}_{50} \\
\mathrm{mg} \mathrm{1}^{-1} \mathrm{Zn}\end{array}$ & $\begin{array}{l}\text { Based on } \\
\text { cell } \\
\text { number, } \\
3 \text { days } \\
(72 \mathrm{~h})\end{array}$ & $\begin{array}{l}\text { Based on } \\
\text { cell } \\
\text { number, } \\
7 \text { days } \\
(168 \mathrm{~h})\end{array}$ & $\begin{array}{l}\text { Based on } \\
\text { Chl } \\
a \text { content, } \\
3 \text { days } \\
(72 \mathrm{~h})\end{array}$ & $\begin{array}{l}\text { Based on } \\
\text { Chl } \\
a \text { content, } \\
7 \text { days } \\
(168 \mathrm{~h})\end{array}$ \\
\hline M. pusillum & 33.69 & 27.7 & 18.79 & 16.99 \\
\hline M. griffithii & 25.63 & 18.36 & 9.53 & 10.07 \\
\hline
\end{tabular}

Green algae used in our study can be regarded as not sensitive to zinc from oxidative stress aspects, and amount of TBARS revealing enhanced lipid peroxidation increased only from relatively high $\left(\geq 20 \mathrm{mg}^{-1}\right)$ zinc concentration.

\section{Removal of zinc}

Zinc removal was followed in significantly affected, but considered as living cultures (from 10 to $40 \mathrm{mg} \mathrm{l}^{-1}$ treatments). Both species were able to remove notable amount of zinc by the end of the experiments (Fig. 5; Table 3). In the case of M. pusillum, zinc removal ability differed significantly in the different treatments and at different exposition times $(P<0.001)$. The highest removal activity appeared in the $20 \mathrm{mg} \mathrm{l}^{-1}$ zinc-treated cultures on the 7th day, $29.3 \mathrm{mg} \mathrm{g}^{-1}$ zinc was removed (Fig. 5a), which meant $52.8 \%$ of the initial zinc content (Table 3). A significant amount of zinc bound quickly at the beginning of the experiments in 20,30 and $40 \mathrm{mg}^{-1}$ zinc-treated cultures. There was no significant correlation between the zinc concentration, exposition time, and the amount of removed zinc (Fig. 5a). Removal ability of M. griffithii cells was different: although significant alterations occurred in zincbinding activity of $M$. griffithii in different treated cultures $(P<0.001)$, the most amount of zinc per unit of dry mass was bound in the $10 \mathrm{mg} \mathrm{l}^{-1}$ treated cultures, on the 3rd day (29.7 $\mathrm{mg} \mathrm{g}^{-1}$, Fig. 5b). Highest removal capacity as percentage of initial zinc content occurred in the same cultures on the 7th day ( $84.8 \%$, Table 3$)$. As it was observed in $M$. pusillum cultures, a significant amount of zinc bound quickly at the beginning of the experiments in 20,30 and $40 \mathrm{mg} \mathrm{l}^{-1}$ zinc-treated $M$. griffithii cultures. The results show that only a small part of total amount of removed zinc

Table 1 Actual zinc concentrations and the calculated amount of precipitated zinc in negative controls (medium + zinc, without algae) after 3 and 7 days of exposition

\begin{tabular}{|c|c|c|c|c|c|c|c|}
\hline Concentration of added $\mathrm{Zn}\left(\mathrm{mg} \mathrm{l}^{-1}\right)$ & 2.5 & 5 & 10 & 15 & 20 & 30 & 40 \\
\hline Actual concentration of $\mathrm{Zn}\left(\mathrm{mg} \mathrm{l}^{-1}\right)$ on the $3 \mathrm{rd}$ day & 1.77 & 4.48 & 8.99 & 13.63 & 18.85 & 28.58 & 38.08 \\
\hline Precipitated $\mathrm{Zn}\left(\mathrm{mg}^{-1}\right)$ on the 3 rd day & 0.73 & 0.52 & 1.01 & 1.37 & 1.15 & 1.43 & 1.92 \\
\hline Actual concentration of $\mathrm{Zn}\left(\mathrm{mg} \mathrm{l}^{-1}\right)$ on the 7 th day & 1.74 & 3.99 & 7.86 & 13.51 & 17.91 & 28.18 & 37.4 \\
\hline Precipitated $\mathrm{Zn}\left(\mathrm{mg}^{-1}\right)$ on the 7 th day & 0.76 & 1.01 & 2.14 & 1.49 & 2.09 & 1.82 & 2.06 \\
\hline
\end{tabular}


is intracellular in the case of both species (Fig. 5c, d). There were no significant effects of zinc concentration and exposition time on intracellular zinc content (Fig. 5c, d).

The results show that removal capacity of $M$. pusillum was the highest at $20 \mathrm{mg} \mathrm{l}^{-1}$ zinc concentration on the 7th day, while in the case of $M$. griffithii maximal zinc removal appeared on the 3rd day in $10 \mathrm{mg}^{-1}$ treated culture. This phenomenon is just the opposite of the observations of Tripathi and Gaur (2004) or Monteiro et al. (2011a, b), they described that the highest zinc mass removal occurred in Scenedesmus cultures exposed to the highest metal concentration. On the other hand, Omar (2002) also observed a decrease in the amount of bound zinc at higher concentrations. It seems that there was a strong primary binding of zinc (at $20-30 \mathrm{mg} \mathrm{l}^{-1}$ ), followed by slower secondary binding. This could explain why the amount of removed zinc increased significantly to the 3 rd and 7 th days in 20-30 $\mathrm{mg}^{-1}$ zinc-treated Monoraphidium cultures. The significant decrease in zinc biosorption in $40 \mathrm{mg}^{-1}$ treated cultures may indicate that there is some (a)

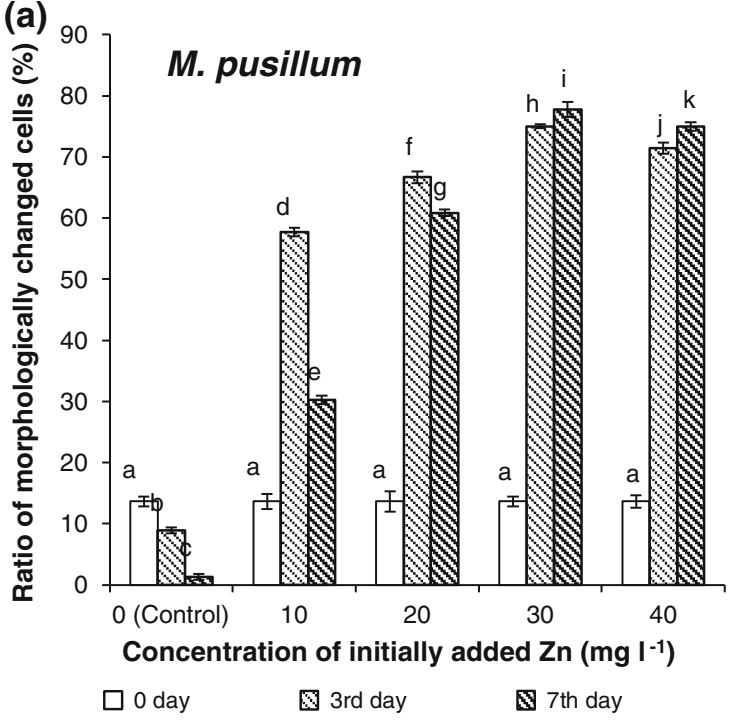

(b)

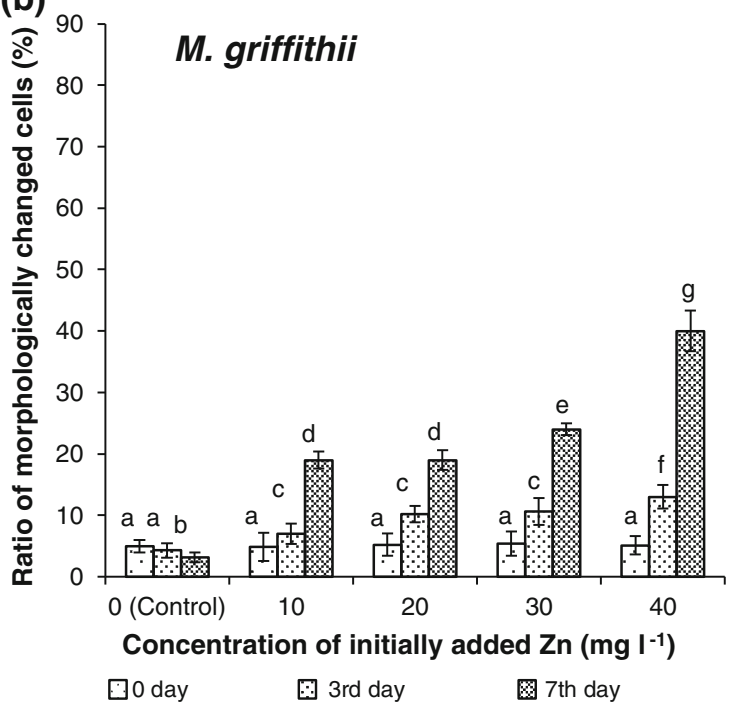

Fig. 3 Ratio of normal and deformed cells in control and in zinc-treated M. pusillum (a) and M. griffithii (b) cultures on day 0, 3, and 7 of cultivation. Mean values $(n=3)$ and standard deviations are plotted, and different lowercase letters indicate significant differences $(P<0.05)$

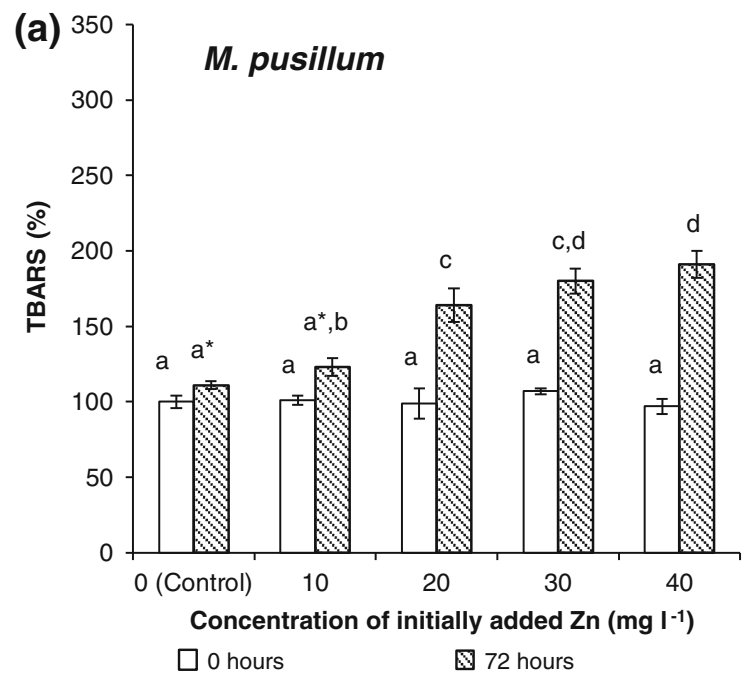

Fig. 4 Lipid peroxidation levels expressed as the amount of TBA reactive substances (\%) in control and in zinc-treated $M$. pusillum (a) and M. griffithii (b) cultures on day 0 and after $72 \mathrm{~h}$ of cultivation.

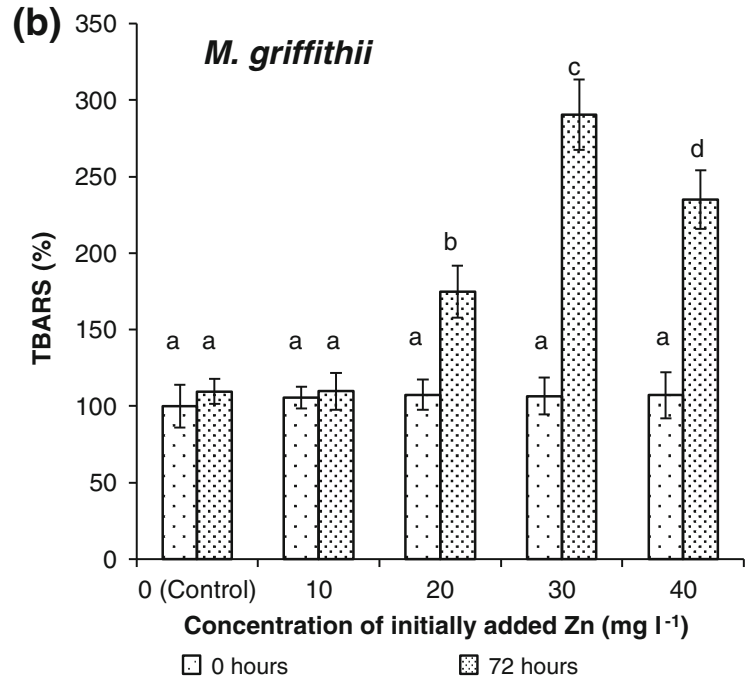

Mean values $(n=3)$ and standard deviations are plotted, and different lowercase letters indicate significant differences $(P<0.05)$ 

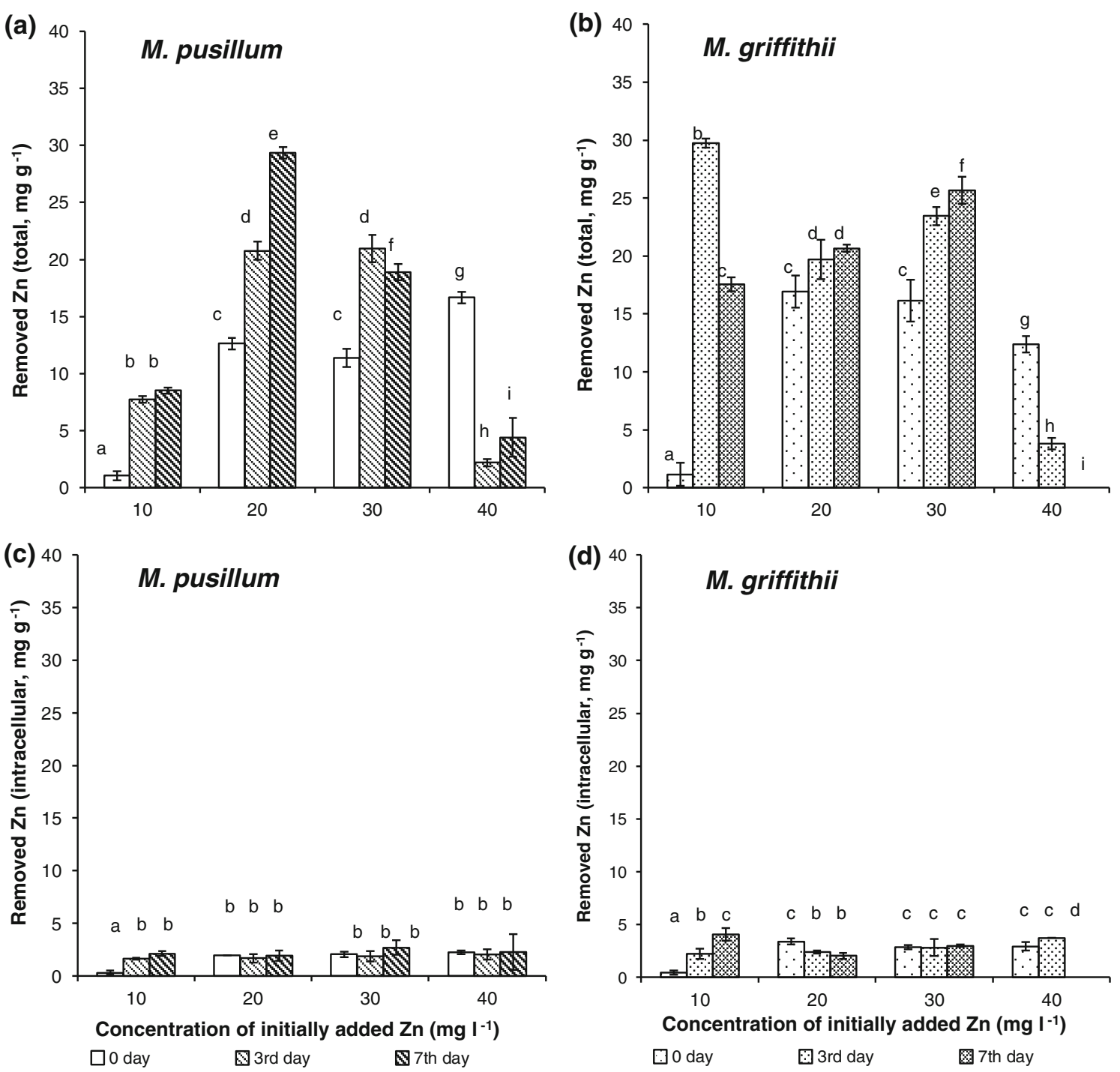

Fig. 5 Total $(\mathbf{a}, \mathbf{b})$ and intracellular (c, d) amount of removed zinc $\left(\mathrm{mg} \mathrm{g}^{-1}\right)$ in zinc-treated $M$. pusillum and $M$. griffithii cultures, on day 0,3 , and 7 of cultivation. Mean values $(n=3)$ and standard

mechanism involved in zinc removal, which modify the binding sites of the cell wall of vital cells, similarly to heating or drying processes (Monteiro et al. 2011b). A partial disruption of structural components in the cell walls owing to high zinc concentration is presumable, which leads to protein denaturation and is thus responsible for the decrease in number of the functional sites available to interact with zinc ions (Monteiro et al. 2011b). Proof of this hypothesis requires further experiments.

The results show that a larger proportion of removed zinc is bound by adsorption onto the cell surface in the case of both studied strains. Only small increases in intracellular zinc were observed with increasing amounts of zinc in the culturing media, which is in accordance with the data of other studies (Hassler et al. 2005; Monteiro et al. 2011a, b). deviations are plotted, and different lowercase letters indicate significant differences $(P<0.05)$

In contrast, in some cases accumulated quantity of metals could be higher than adsorbed, as for certain $C$. vulgaris strains or other bioaccumulators (Nacorda et al. 2007).

As in the case of growth, comparison of the literature data with each other and with our results may not be entirely accurate because of different measured growth parameters, exposition times, and different extrapolation of measured data. It seems that zinc-binding ability of the studied species is in the "medium range" in comparison with that of some other green algae, similarly to their zinc tolerance. There are more capable isolates: Schmitt et al. (2001) claimed maximum specific adsorption capacities of $72.06 \mathrm{mg} \mathrm{g}^{-1}$ for Scenedesmus subspicatus (exposed to $0.5 \mathrm{mg} \mathrm{l}^{-1}$ zinc for 4 days), Ahuja et al. (2001) also reported higher zinc removal ability for the cyanobacterium Oscillatoria 
Table 3 Amount of removed zinc interpreted as per unit of dry mass and as percentage of initial zinc content

\begin{tabular}{|c|c|c|}
\hline & M. pusillum & M. griffithii \\
\hline Max. removed $\mathrm{Zn}\left(\mathrm{mg} \mathrm{g}^{-1}\right)$ & 29.33 (7th day, $20 \mathrm{mg} \mathrm{l}^{-1}$ ) & 29.74 (3rd day, $10 \mathrm{mg} \mathrm{l}^{-1}$ ) \\
\hline Max. removed $\mathrm{Zn}, \%$ of initial $\mathrm{Zn}$ concentration & 52.8 (7th day, $20 \mathrm{mg} \mathrm{l}^{-1}$ ) & 84.8 (7th day, $10 \mathrm{mg}^{-1}$ ) \\
\hline
\end{tabular}

Exposition times and added zinc concentrations belonging to the maximal removed value are also indicated

angustissima (35.7 and $83.4 \mathrm{mg} \mathrm{g}^{-1}$; exposed to 20 and $30 \mathrm{mg} \mathrm{l}^{-1}$ zinc, respectively for after 10 days). High zinc adsorption was reported for an other $O$. angustissima strain and for Microcystis sp. (641.25 and $999.5 \mathrm{mg} \mathrm{g}^{-1}$, respectively; Ahuja et al. 1999; Pradhan et al. 1998). Otherwise, the application of these cyanobacteria as biosorbents is questionable, because of their possible toxic properties (Vasas et al. 2010, 2013). Some species of the family Scenedesmaceae can be considered as outstanding zinc binders, 360 and $103 \mathrm{mg} \mathrm{g}^{-1}$ bound zinc were reported for a Desmodesmus pleimorphus isolate and a laboratory strain, respectively, (Monteiro et al. 2009) and 836,5 $\mathrm{mg} \mathrm{g}^{-1}$ was reported for a Scenedesmus oblicuus strain (Monteiro et al. 2011b). On the other hand, there are strains, which can be characterized more comparable or even weaker zinc-binding ability, than the ones in our study: Romera et al. (2007) reported that the filamentous green alga Spirogyra insignis removed a maximum of $21.1 \mathrm{mg} \mathrm{g}^{-1}$ of zinc, PawlikSkowrońska (2003) reported $8.1 \mathrm{mg} \mathrm{g}^{-1}$ for an other filamentous green alga, Stigeoclonium tenиe (exposure to $2 \mathrm{mg} \mathrm{l}^{-1}$ zinc for 3 weeks). A strain of Scenedesmus quadricauda removed $5.03 \mathrm{mg} \mathrm{g}^{-1}$ zinc after $24 \mathrm{~h}$ incubation from solutions ranging from 0.5 to $11 \mathrm{mg} \mathrm{l}^{-1}$ (Omar 2002), similar amount $\left(5 \mathrm{mg} \mathrm{g}^{-1}\right)$ was reported for Euglena gracilis (Fukami 1988).

The most common arrangements used for the removal of inorganic contaminants are high-rate algal ponds (HRAP) and the patented algal turf scrubber (ATS), which employs suspended biomass of common green algae, cyanobacteria or consortia of both (Perales-Vela et al. 2006). Algal species, which are common in the environment of the planned localities of these kinds of ponds, could be more suitable to inoculate and maintain these systems than species from an entirely different environment. On the basis of the results presented here, it can be concluded that there are common green algal species in surface waters, whose tolerance to zinc and zinc-binding ability makes them feasible in treatment of wastewaters with $1-20 \mathrm{mg}^{-1}$ zinc contamination.

\section{Conclusion}

Based on these results, it can be concluded that the studied green algal species are zinc tolerant; they are able to survive relatively high zinc concentrations. This paper provides new data for the zinc tolerance and zinc removal ability of the green algae M. pusillum and M. griffithii. Both species are able to remove significant amount of zinc, and the larger proportion of removed zinc is bound by adsorption onto the cell surface. Living biomass of the studied species could be applicable for biosorption, 3-7 days exposition up to $20 \mathrm{mg}^{-1}$ zinc concentration at $\mathrm{pH}$ 7-7.5. It can be concluded that living biomass of the studied strains-common algal species in Hungarian surface waters-as newly introduced metal tolerant species could be good alternatives for application and/or bases of future research.

Acknowledgments The research was supported by the EU and cofinanced by the European Social Fund under the project ENVIKUT (TÁMOP-4.2.2.A-11/1/KONV-2012-0043), by the Internal Research Project of the University of Debrecen and by the János Bolyai Research Scholarship of the Hungarian Academy of Sciences.

\section{References}

Ahuja P, Gupta R, Saxena RK (1999) $\mathrm{Zn}^{2+}$ biosorption by Oscillatoria angustissima. Proc Biochem 34:77-85

Ahuja P, Mohapatra H, Saxena RK, Gupta R (2001) Reduced uptake as a mechanism of zinc tolerance in Oscillatoria angustissima. Curr Microbiol 43:305-310

Andrade LR, Farina M, Amado-Filho GM (2004) Effects of copper on Enteromorpha flexuosa (Chlorophyta) in vitro. Ecotoxicol Environ Saf 58:117-125

Bates SS, Tessier A, Campbell PGC, Buffle J (1982) Zinc adsorption and transport by Chlamydomonas variabilis and Scenedesmus subspicatus (Chlorophyceae) grown in semicontinuous culture. J Phycol 18:521-529

Bird G, Brewer PA, Macklin MG, Balteanu D, Driga B, Serban M, Zaharia S (2003) The solid state partitioning of contaminant metals and As in river channel sediments of the mining affected Tisa drainage basin, northwestern Romania and eastern Hungary. Appl Geochem 18:1583-1595

Brinza L, Dring MJ, Gavrilescu M (2007) Marine micro- and macroalgal species as biosorbents for heavy metals. Environ Eng Manag J 6:237-251

Broadley MR, White PJ, Hammond JP, Zelko I, Lux A (2007) Zinc in plants. New Phytol 173:677-702

Chojnacka K (2010) Biosorption and bioaccumulation-the prospects for practical applications. Environ Int 36:299-307

Cobbett C, Goldsbrough P (2002) Phytochelatin and metallothioneins: roles in heavy metal detoxification and homeostasis. Annu Rev Plant Biol 53:159-182

Cotton FA, Wilkinson G, Murillo CA, Bochmann M (1999) Advanced inorganic chemistry, 6th edn. John Wiley \& Sons Inc., New York

Das N (2010) Recovery of precious metals through biosorption-a review. Hydrometallurgy 103:180-189 
de Bashan LE, Bashan Y (2010) Immobilized microalgae for removing pollutants: review of practical aspects. Bioresource Technol 101:1611-1627

de Queiroz JC, de Melo Ferreira AC, da Costa ACA (2012) The growth of Monoraphidium sp. and Scenedesmus sp. cells in the presence of thorium. Sci World J. doi:10.1100/2012/592721

Eisler R (1993) Zinc hazard to fish, wildlife, and invertebrates: a synoptic review. Contam Hazard Rev 10:1-126

Felföldy L (1987) A biológiai vízminősítés. 4. kiad. In: Vízügyi Hidrobiológia 16. VGI, Budapest, 258

Fosmire GJ (1990) Zinc toxicity. Am J Clin Nutr 51:225

Fujii K, Nakashima H, Hashidzume Y, Uchiyama T, Mishiro K, Kadota Y (2009) Nutritional profile of Monoraphidium sp. GK12, astaxanthin-producing microalga, and its energy-saving outdoor cultivation. J Biosci Bioeng 108(1):S44

Fukami M (1988) Effects of zinc on metal metabolism on the zinc tolerant chlorotic mutants of Euglena gracilis. J Agric Biol Chem 52:2343-2344

Gattullo CE, Bährs H, Steinberg CEW, Loffredo E (2012) Removal of bisphenol A by the freshwater green alga Monoraphidium braunii and the role of natural organic matter. Sci Total Environ 416:501-506

Gold C, Feurtet-Mazel A, Coste M, Boudou A (2003) Impacts of Cd and $\mathrm{Zn}$ on the development of periphytic diatom communities in artificial streams located along a river pollution gradient. Arch Environ Contam Toxicol 44:189-197

Hammer $\check{R}$, Harper DAT, Ryan PD (2001) PAST: paleontological statistics software package for education and data analysis. Palaeontol Electron 4:9

Hassler CS, Behra R, Wilkinson KJ (2005) Impact of zinc acclimation on bioaccumulation and homeostasis in Chlorella kesslerii. Aquat Toxicol 74:139-149

Hornstrom E, Harbom A, Edberg F, Andren C (1995) The influence of $\mathrm{pH}$ on aluminium toxicity in the phytoplankton species Monoraphidium dybowskii and M. griffithii. Water Air Soil Poll 85(2):817-822

Horváth B, Gruiz K (1996) Impact of metalliferous ore mining activity on the environment in Gyongyosoroszi, Hungary. Sci Total Environ 184:215-227

Hussein H, Farag SI, Kamal K, Moawad H (2004) Biosorption of heavy metals from waste water using Pseudomonas sp. Electron J Biotechnol 7(1):39-46

Kapoor A, Viraraghavan T (1995) Fungal biosorption—an alternative treatment option for heavy metal bearing wastewater: a review. Bioresour Technol 53(3):195-206

Lehmann V, Tubbing GMJ, Admiraal W (1998) Induced metal tolerance in microbenthic communities from three lowland rivers with different metal loads. Arch Environ Contam Toxicol 36:384-391

Li M, Hu C, Zhu Q, Chen L, Kong Z, Liu Z (2006) Copper and zinc induction of lipid peroxidation and effects on antioxidant enzyme activities in the microalga Pavlova viridis (Prymnesiophyceae). Chemosphere 62:565-572

Malea P, Rijstenbil JW, Haritonidis S (2006) Effects of cadmium, zinc and nitrogen status on non-protein thiols in the macroalgae Enteromorpha spp. from the Scheldt Estuary (SW Netherlands, Belgium) and Thermaikos Gulf (N Aegean Sea, Greece). Mar Environ Res 62:45-60

Monteiro CM, Marques APGC, Castro PML, Malcata FX (2009) Characterization of Desmodesmus pleiomorphus isolated from a heavy metal-contaminated site: biosorption of zinc. Biodegradation 20:629-641

Monteiro CM, Fonseca SC, Castro PML, Malcata FX (2011a) Toxicity of cadmium and zinc on two microalgae, Scenedesmus obliquus and Desmodesmus pleiomorphus, from Northern Portugal. J Appl Phycol 23:97-103
Monteiro CM, Castro PML, Malcata FX (2011b) Biosorption of zinc ions from aqueous solution by the microalga Scenedesmus obliquus. Environ Chem Lett 9:169-176

Morin S, Coste M (2006) Metal-induced shifts in the morfology of diatoms from Riou Mort and Riou Vioi streams (South West France). Arch Hydrobiol-Supplement 97-101

Munoz R, Guieysse B (2006) Algal-bacterial processes for the treatment of hazardous contaminants: a review. Water Res 40:2799-2815

Muyssen BTA, De Schamphelaere KAC, Janssen CR (2006) Mechanisms of chronic waterborne $\mathrm{Zn}$ toxicity in Daphnia magna. Aquat Toxicol 77:393-401

Nacorda JO, Martinez-Goss MR, Torreta NK, Merca FE (2007) Metal resistance and removal by two strains of the green alga, Chlorella vulgaris Beijerinck, isolated from Laguna de Bay, Philippines. J Appl Phycol 19:701-710

Nishikawa K, Tominaga N (2001) Isolation, growth, ultrastructure, and metal tolerance of the green alga Chlamydomonas acidophila (Chlorophyta). Biosci Biotechnol Biochem 65: 2650-2656

Ódor L, Richard BW, Horváth I, Fügedi U (1998) Mobilization and attenuation of metals downstream from a base-metal mining site in the Mátra Mountains, northeastern Hungary. J Geochem Explor 65:47-60

Omar HH (2002) Bioremoval of zinc ions by Scenedesmus obliquus and Scenedesmus quadricauda and its effect on growth and metabolism. Int biodeterior Biodegrad 50:95-100

Palmieria MC, Garcia O, Melnikov P (2000) Neodymium biosorption from acidic solutions in batch system. Process Biochem $36: 441-444$

Pawlik-Skowrońska B (2003) Resistance, accumulation and allocation of zinc in two ecotypes of the green alga Stigeoclonium tenue Kütz. coming from habitats of different heavy metal concentrations. Aquat Bot 75:189-198

Perales-Vela HV, Pena-Castro JM, Canizares-Villaneuva RO (2006) Heavy metal detoxification in eukaryotic microalgae. Chemosphere 64:1-10

Perovic S, Tretter L, Brummer F, Wetzler C, Brenner J, Donner G, Schroder HC, Muller WEG (2000) Dinoflagellates from marine algal blooms produce neurotoxic compounds: effects on free calcium levels in neuronal cells and synaptosomes. Environ Toxicol Pharmacol 8(2):83-94

Pradhan S, Sing S, Rai LC, Parker DL (1998) Evaluation of metal biosorption efficiency of laboratory-grown Microcystis under various environmental conditions. J Microbiol Biotechnol 8:53-60

Prasad AS (2008) Zinc in human health: effect of zinc on immune cells. Mol Med 14:353

Romera E, Gonzalez F, Ballester A, Blazquez ML, Munoz JA (2006) Biosorption with algae: a statistical review. Crit Rev Biotechnol 26:223-235

Romera E, González F, Ballester A, Blázquez ML, Muñoz JA (2007) Comparative study of biosorption of heavy metals using different types of algae. Bioresour Technol 98:3344-3353

Schmitt D, Müller A, Csögör Z, Frimmel FH, Posten C (2001) The adsorption kinetics of metal ions onto different microalgae and siliceous earth. Water Res 35:779-785

Sugarman B (1983) Zinc and infection. Rev Infect Dis 5:137

Takami R, Almeida JV, Vardaris CV, Colepicolo P, Barros MP (2012) The interplay between thiol-compounds against chromium (VI) in the freshwater green alga Monoraphidium convolutum: toxicology, photosynthesis, and oxidative stress at a glance. Aquat Toxicol 118-119:80-87

Travieso L, Canizares RO, Borja R, Benitez F, Dominguez AR, Dupeyron R, Valiente V (1999) Heavy metal removal by microalgae. Bull Environ Contam Toxicol 62:144-151 
Tripathi BN, Gaur JP (2004) Relationship between copper- and zincinduced oxidative stress and proline accumulation in Scenedesmus sp. Planta 219:397-404

Tripathi BN, Gaur JP (2006) Physiological behavior of Scenedesmus sp. during exposure to elevated levels of $\mathrm{Cu}$ and $\mathrm{Zn}$ and after withdrawal of metal stress. Protoplasma 229:1-9

Tsuji N, Hirayanagi N, Okada M, Miyasaka H, Hirata K, Zenk MH, Miyamotoa K (2002) Enhancement of tolerance to heavy metals and oxidative stress in Dunaliella tertiolecta by $\mathrm{Zn}$-induced phytochelatin synthesis. Biochem Biophys Res Commun 293:653-659

Vasas G, Bácsi I, Surányi G, Hamvas MM, Mathe C, Nagy SA, Borbely G (2010) Isolation of viable cell mass from frozen Microcystis viridis bloom containing microcystin-RR. Hydrobiologia 639:147-151

Vasas G, M-Hamvas M, Borics G, Gonda S, Mathe C, Jambrik K, Nagy ZL (2012) Occurrence of toxic Prymnesium parvum blooms with high protease activity is related to fish mortality in Hungarian ponds. Harmful Algae 17:102-110

Vasas G, Farkas O, Borics G, Felföldi T, Sramkó G, Batta G, Bácsi I, Gonda S (2013) Appearance of Planktothrix rubescens Bloom with [D-Asp3, Mdha7]MC-RR in Gravel Pit Pond of a Shallow Lake-dominated area. Toxins 5:2434-2455

Vavilin DV, Ducruet JM, Matorin DN, Venediktov PS, Rubin AB (1998) Membrane lipid peroxidation, cell viability and photosystem II activity in the green alga Chlorella pyrenoidosa subjected to various stress conditions. J Photochem Photobiol B Biol 42:233-239
Verma S, Dubey RS (2003) Lead toxicity induces lipid peroxidation and alters the activities of antioxidant enzymes in growing rice plants. Plant Sci 164(4):645-655

Visviki I, Rachlin JW (1991) The toxic action and interactions of copper and cadmium to the marine alga Dunaliella minuta, in both acute and chronic exposure. Arch Environ Contam Toxicol 20:271-275

Volesky B (1990a) Biosorption and biosorbents. In: Biosorption of heavy metals. CRC press, Boston

Volesky B (1990b) Removal and recovery of heavy metals by biosorption. In: Biosorption of heavy metals. CRC press, Boston

Wang JL, Chen C (2009) Biosorbents for heavy metals removal and their future. Biotech Adv 27:195-226

Yang X, Liu P, Hao Z, Shi J, Zhang S (2012) Characterization and identification of freshwater microalgal strains toward biofuel production. Bioresources 7(1):686-695

Yu X, Zhao P, He C, Li J, Tang X, Zhou J, Huang Z (2012) Isolation of a novel strain of Monoraphidium sp. and characterization of its potential application as biodiesel feedstock. Bioresour Technol 121:256-262

Zar JH (1996) Biostatical analysis, 3rd edn. Prentice Hall, Upper Saddle River

Zhang QC, Qiu LM, Yu RC, Kong FZ, Wang YF, Yan T, Gobler CJ, Zhou MJ (2012) Emergence of brown tides caused by Aureococcus anophagefferens Hargraves et Sieburth in China. Harmful Algae 19:117-124 